\title{
A mudança na produção de fricativas em coda medial por uma criança recifense residente em João Pessoa
}

\author{
The change in production of medial coda fricatives by a child from Recife living \\ in João Pessoa
}

\author{
Pedro Felipe de Lima Henrique \\ Ingrid Cruz do Nascimento* \\ Lucas Possatti**
}

\begin{tabular}{|c|c|}
\hline $\begin{array}{l}\text { RESUMO: Este estudo compara a } \\
\text { produção de fricativas em coda medial de } \\
\text { uma informante recifense de } 10 \text { anos, } \\
\text { residente em João Pessoa-PB, com a } \\
\text { produção de duas crianças pessoenses e } \\
\text { duas recifenses de mesma idade, que } \\
\text { nunca saíram de sua comunidade de fala, } \\
\text { averiguando em que medida a criança } \\
\text { que mudou de cidade assimilou o dialeto } \\
\text { pessoense. A diferença entre o } \\
\text { comportamento da fricativa em Recife- } \\
\text { PE, onde predomina a forma palatalizada } \\
\text { (MACEDO, 2004), e em João Pessoa-PB, } \\
\text { onde predomina a forma alveolar } \\
\text { (HORA, 2003), suscitou a seleção da } \\
\text { variável. Coletaram-se amostras de fala } \\
\text { mediante inquérito fonético, leitura } \\
\text { monitorada e entrevista semiestruturada. } \\
\text { As palavras dos primeiros instrumentos } \\
\text { foram escolhidas pensando-se no } \\
\text { contexto fonológico anterior e seguinte, } \\
\text { considerados como variáveis }\end{array}$ & $\begin{array}{l}\text { ABSTRACT: This study compares the } \\
\text { production of medial coda fricatives of a } \\
\text { 10-year-old participant from Recife who } \\
\text { currently lives in João Pessoa-PB, with the } \\
\text { production of four children of the same } \\
\text { age (two from João Pessoa and two from } \\
\text { Recife), who never left their speech } \\
\text { communities, in order to analyze to what } \\
\text { extent the child who moved to João } \\
\text { Pessoa-PB assimilated the local dialect. } \\
\text { The variable was selected due to the } \\
\text { difference between the behavior of the } \\
\text { fricative in Recife-PE, where the } \\
\text { palatalized form is predominant } \\
\text { (MACEDO, 2004), and in João Pessoa-PB, } \\
\text { where the alveolar form is predominant } \\
\text { (HORA, 2003). Speech samples were } \\
\text { collected through phonetic inquiry, } \\
\text { monitored reading and semi-structured } \\
\text { interview. The words for the two first } \\
\text { instruments were chosen considering the } \\
\text { phonological context that came before }\end{array}$ \\
\hline
\end{tabular}

\footnotetext{
* Professor do Instituto Federal do Rio Grande do Norte (IFRN) e doutorando em Linguística pelo Programa de Pós-Graduação em Linguística (Proling) da Universidade Federal da Paraíba (UFPB). http://orcid.org/0000-0001-8819-3588, pedrofelipelh@hotmail.com

** Mestranda em Linguística pelo Programa de Pós-Graduação em Linguística (Proling) da Universidade Federal da Paraíba (UFPB), Bolsista Capes. http://orcid.org/0000-0002-9448-2121, ingridcruznascimento@gmail.com

*** Mestrando em Linguística pelo Programa de Pós-Graduação em Linguística (Proling) da Universidade Federal da Paraíba (UFPB), bolsista Capes. http://orcid.org/0000-0002-0244-2190, lpossatti@yahoo.com
} 
independentes para a aplicação da regra de palatalização. Analisaram-se as fricativas no Praat (BOERSMA; WEENINK, 2009) atentando para o pico espectral, que indicou o grau de palatalização (HENRIQUE et al., 2015), considerado como variável dependente. Como resultados, constatou-se que as fricativas produzidas pela informante recifense, residente em João Pessoa, não apresentaram diferença significativa com relação às crianças pessoenses, diferentemente das produzidas pelas crianças recifenses. Inferiu-se, portanto, que a criança assimilou o dialeto da comunidade onde vive atualmente, que tem apenas o contexto coronal /t/ e /d/ como gatilho para a palatalização. Analisam-se esses resultados à luz do processo de aquisição do segmento fricativo em coda por crianças (OLIVEIRA, 2002; MEZZOMO, 2003; BERTI, 2006) e de novas perspectivas inerentes à Sociolinguística e à comunidade de fala (LABOV, 2008; GUY, 2000).

PALAVRAS-CHAVE: Fricativa coronal em coda medial. Variação linguística. Aquisição da linguagem. Acomodação dialetal. and after the coda fricative, which in turn were considered as independent variables for the application of the rule of palatalization. The fricatives were analyzed in Praat (BOERSMA; WEENINK, 2009) considering the spectral peak, which indicated the degree of palatalization (HENRIQUE et al., 2015), considered as a dependent variable. The results show that the fricatives produced by the participant from Recife living in João Pessoa did not present a significant difference in relation to the children from João Pessoa, unlike the ones produced by the children from Recife. It was inferred, therefore, that the child assimilated the dialect of the community in which she currently lives, which only has the coronal context $/ \mathrm{t} /$ and $/ \mathrm{d} / \mathrm{as}$ a trigger for palatalization. We analyzed these results in the light of the process of acquisition of the fricative segment in coda by children (OLIVEIRA, 2002; MEZZOMO, 2003; BERTI, 2006) and of new perspectives in Sociolinguistics regarding the speech community (LABOV, 2008 [1972]; GUY, 2000).

KEYWORDS: Coronal fricative in medial coda. Language variation. Language acquisition. Dialectical accommodation.

\section{Considerações iniciais}

A interação social mediante a comunicação oral é extremamente importante e está presente nas mais diversas atividades humanas. Numa interação de comunicação, um falante pode desejar se aproximar, ganhar aceitação, ou se distanciar e se desassociar de outro(s) indivíduo(s). Conscientemente ou não, realizamos ajustes na fala para que tais objetivos sejam atingidos, pois esses ajustes são meios de expressar intenções, valores e atitudes (GILES et al., 1982). Os estudos 
sobre acomodação originaram-se na Psicologia Social, passando por diversas mudanças ao longo do tempo, culminando na criação da Teoria da Acomodação da Fala (GILES, 1973 apud GILES et al., 1991) que, em seguida, tornou-se a Teoria da Acomodação da Comunicação. Esta engloba, além dos padrões de comportamentos da fala, aspectos não verbais, como os gestos, a velocidade de fala, as pausas, entre outros. Baseado na Teoria da Acomodação da Comunicação, de Giles (1973 apud GILES et al., 1991), Trudgill (1986) estuda os fatores que determinam a acomodação dialetal, assim como a extensão e a percepção dessa acomodação, lidando com os motivos e as maneiras pelas quais as variedades linguísticas influenciam umas às outras.

A acomodação linguística, de acordo com Trudgill (1986), efetiva-se de duas maneiras: a curto prazo e a longo prazo. A primeira ocorre com ajustes que são feitos no momento em que o falante, conscientemente ou não, julga serem necessários, de acordo com a situação de comunicação. Com a imersão em uma comunidade de fala e a ocorrência frequente dessas acomodações de curto prazo, elas se rotinizam, fazendo com que o falante aos poucos aproxime sua fala à fala local, resultando em uma acomodação de longo prazo. Esta, por sua vez, ocorre quando o falante modifica sua fala a tal ponto que ela já não depende tanto da situação. Como se pode imaginar, são vários os fatores (linguísticos e extralinguísticos) que podem favorecer ou inibir esse processo, tais como o tempo de permanência na comunidade e os segmentos fonéticos adjacentes aos que apresentam variação.

No Português Brasileiro (PB), a aquisição da fricativa coronal em coda, segundo Mezzomo (2003), ocorre primeiro na posição final (como em trê/S/ e mai/S/), aos dois anos e seis meses; na posição medial (como em fe/S/ta e me/S/mo), aos três anos de idade. Isto se justifica devido à complexidade articulatória de uma sílaba travada ser realizada por uma criança, tendo em vista, por exemplo, limitações de memória e o desenvolvimento de seu aparelho fonador, inerentes a 
essa fase da vida. Além disso, em relação à estabilização do fenômeno fonológico, Mezzomo (2003) afirma que a coda se regulariza entre três anos e dois meses e três anos e oito meses de idade. Durante esse período, caso a criança se insira em uma comunidade de fala diferente da sua, espera-se, consequentemente, que haja um processo de acomodação linguística.

Assim sendo, este estudo analisa a produção de fricativas em coda medial de uma informante recifense de 10 anos, residente em João Pessoa-PB, comparando-as com a produção da mesma variável de duas crianças pessoenses e recifenses de mesma idade, que nunca saíram de sua comunidade de fala, objetivando averiguar em que medida a criança que mudou de cidade assimilou o dialeto pessoense. A diferença entre o comportamento da fricativa em Recife-PE, onde predomina a forma palatalizada (MACEDO, 2004), e em João Pessoa-PB, onde predomina a forma alveolar (HORA, 2003), suscitou a seleção da variável.

Assim, realizou-se uma coleta única de amostras de fala por meio de inquérito fonético (as crianças diziam o nome das figuras que lhes eram apresentadas), leitura monitorada (liam um texto com palavras com as variáveis selecionadas) e entrevista semiestruturada, realizados com as cinco estudantes mencionadas. As palavras do inquérito fonético e da leitura foram escolhidas pensando-se no contexto fonológico anterior e seguinte, considerados como variáveis independentes para a aplicação da regra de palatalização. Analisaram-se as fricativas no Praat (BOERSMA; WEENINK, 2009), atentando para o pico espectral em determinadas regiões de frequência, que indicou o grau de palatalização da fricativa (HENRIQUE et al., 2015) e foi considerado como variável dependente.

O presente trabalho, assim, divide-se em quatro seções. A primeira apresenta os objetivos e as contribuições da Sociolinguística e da aquisição da linguagem, bem como a relação entre essas áreas para os estudos linguísticos. A segunda, por sua vez, expõe o comportamento das fricativas coronais em coda silábica em diferentes 
comunidades de fala. Já a terceira é constituída pela metodologia utilizada e descreve o desenho dos instrumentos de coleta e análise da pesquisa. Por fim, na última seção encontram-se as discussões dos resultados obtidos.

\section{Pressupostos teóricos}

Pesquisas com foco na língua, no século $X X$, passaram a se interessar não apenas pelos aspectos formais do sistema linguístico, mas também pelo seu uso. Assim surge a Sociolinguística, ramo da Linguística que ganha força com os estudos de William Labov (2008) e objetiva compreender a relação entre a língua e os fatores sociais. A língua é tratada como um sistema dinâmico, que está sempre em mudança, e heterogêneo. A partir do contexto linguístico, as mudanças da língua podem ser observadas e previstas, e com um tratamento longitudinal dos dados, pode-se observar o progresso dessas mudanças. Então, a Sociolinguística utiliza-se de levantamentos estatísticos que incluem variáveis linguísticas e extralinguísticas para sistematizar e observar as variações que ocorrem na língua.

Nos estudos linguísticos que buscam analisar a fala, os dados são coletados de indivíduos, mas estes fazem parte de um grupo maior, que é denominado de 'comunidade de fala'. Guy (2000) define bem a comunidade de fala de acordo com suas funções e características dentro da Sociolinguística. Como funções ele menciona duas, sendo a primeira a de criar uma base que explique a distribuição social de semelhanças e diferenças linguísticas, e a segunda a de justificar a união dos idioletos de falantes individuais (objeto observável) em objetos maiores. Quanto às características da comunidade de fala, ele resume-as de maneira a listar que uma comunidade de fala possui (i) “características linguísticas compartilhadas" entre a comunidade, mas não com os que não fazem parte dela; (ii) "densidade de comunicação interna relativamente alta", que quer dizer que a comunicação ocorre mais dentro da comunidade de fala do que fora dela; e (iii) "normas 
compartilhadas", que abarcam atitudes linguísticas e variação estilística (GUY, 2000, p. 18). O autor ressalta que é pela utilização ou não dos traços linguísticos de uma comunidade de fala que o falante se mostra pertencer ou não àquela comunidade.

Sentir-se pertencente a um grupo ou, neste caso, a uma comunidade de fala, pode ser algo não tão simples de ocorrer (como quando o falante sofre preconceito linguístico, por exemplo). Isso acontece porque, afinal, a fala revela muito sobre a identidade de um indivíduo e, a depender das atitudes e das opiniões deste para com outra comunidade de fala, a acomodação pode ser inibida ou favorecida. Sendo assim, o fator identidade e também fatores sociais que atribuem prestígio a um determinado grupo podem ser determinantes para o processo de acomodação numa situação de contato entre comunidades de fala. Quando estas, por exemplo, são geograficamente próximas umas às outras e seus falantes entram em contato, as diferentes características linguísticas costumam se sobressair. Para os falantes envolvidos nesse processo, pode ser importante acomodar o modo de falar ao do interlocutor. Este trabalho enquadra-se nesse arcabouço, pois busca compreender de que modo uma criança recifense acomoda as fricativas alveolares em coda medial, variante prototípica dos falantes pessoenses.

$\mathrm{Na}$ área da Sociolinguística variacionista, há diversos estudos envolvendo acomodação dialetal. Embora não numerosos no Brasil, eles vêm crescendo nos últimos tempos, a exemplo Marques (2006), Martins (2008), Chacon (2012), Lima (2013) e Possatti (2015). Essas pesquisas foram realizadas à luz dos pressupostos teóricos da Teoria da Acomodação da Comunicação (GILES et al., 1991) e dos aportes teórico-metodológicos da Teoria da Variação Linguística (LABOV, 2008).

\subsection{Estudos sobre a aquisição das fricativas por crianças}

Ainda acerca do fenômeno linguístico mencionado, outras análises são realizadas com um foco distinto, por exemplo, o da aquisição da linguagem, 
buscando compreender de que modo a criança adquire suas variantes. Estudos como os de Oliveira (2002), Mezzomo (2003) e Berti (2006) são caros ao desenvolvimento deste trabalho.

Oliveira (2002) descreve a aquisição das fricativas /f/, /v/, /J/ e /3/ do português brasileiro, em posição de onset simples (absoluto e medial), por crianças com desenvolvimento normal, e idade entre 1:0 e 3:8 anos. O intuito era observar o que ocorria quando a criança não produzia um dos segmentos em estudo e quando estes eram substituídos. Os dados analisados foram extraídos do banco de dados Inifono (crianças com idade entre 1:0 e 1:11 anos) e Aquifono (crianças com idade entre 2:0 e 7:1 anos), da Universidade Católica de Pelotas. Dentre os resultados observados, os que interessam ao estudo aqui proposto são: (i) há diferentes etapas de aquisição na classe das fricativas: primeiro tem-se o /v/ e o /f/, depois /z/ e /s/, e por último, o /S/ e o /3/; (ii) a idade de aquisição desses fonemas foi: /v/ com 1:8 > /f/ com 1:9>/J/ com 2:6 > /3/ com 2:10; e (iii) a faixa etária foi apontada como a variável mais relevante para aquisição para os quatro fonemas.

Mezzomo (2003) analisaram, por meio de uma comparação de dados transversais (mais de uma criança ao longo do tempo) e longitudinais (uma única criança ao longo do tempo), a aquisição da coda medial e final dos arquifonemas $/ \mathrm{N}$, L, S, R/, no PB, em crianças entre 1:2 anos e 3:8 anos. Como resultados, Mezzomo (2003) afirmam que a aquisição do /S/ ocorre primeiro na coda final (como em trê/S/ e mai/S/), aos 2:6 anos, enquanto na coda medial (como em ca/S/ca e me/S/mo) se dá aos 3:0 anos, o que se explica devido à dificuldade de uma sílaba travada ser realizada por uma criança. Além disso, em relação à estabilização do fenômeno fonológico, Mezzomo (2003) afirmam que, nos dados transversais, a coda se regulariza aos 3:8 anos; nos dados longitudinais, aos 3:2 anos.

Berti (2006) investigou o estabelecimento do contraste entre as fricativas /s/ e / $/$ / em crianças com e sem queixas fonoaudiológicas falantes do PB. Para interpretar 
o estabelecimento dessa distinção, a pesquisadora realizou um estudo de produção e outro de percepção da fala. O primeiro compreendeu a análise acústica da fala de seis crianças (três com queixas fonoaudiológicas e três sem queixas fonoaudiológicas) de ambos os sexos entre cinco e sete anos de idade, a partir da produção de seis palavras dissílabas paroxítonas contendo as fricativas /s/ e /J/ acompanhadas das vogais /i/, /a/ e /u/. Os parâmetros acústicos adotados na análise foram os relativos às características acústicas do ruído fricativo (os quatro momentos espectrais), os relativos às características acústicas das vogais adjacentes às fricativas (medidas de formantes e trajetória formântica) e os relativos ao padrão temporal. A partir dos resultados desse estudo, Berti (2006) constatou uma gradiência entre as categorias /s/ e / / nas produções das crianças com queixas fonoaudiológicas, o que pode sugerir uma aquisição incompleta desse contraste fônico.

A partir dos estudos reportados acima, observa-se que os segmentos fricativos palatais, em posição de onset, são adquiridos mais tardiamente, segundo Oliveira (2002), em relação aos labiais e alveolares. Observa-se também que, em posição de coda medial, de acordo com Mezzomo (2003), as fricativas coronais são adquiridas entre os 3:0 e os 3:8 anos. Por fim, o trabalho de Berti (2006) alude ao caráter gradiente do estabelecimento de contrastes entre os segmentos alveolar e palatal. Com base nesses resultados, é razoável pensar que a idade em que a criança muda de comunidade de fala pode ser um fator importante para entender as possíveis alterações nos padrões de produção de certos segmentos, principalmente aqueles que ainda estiverem em fase de aquisição, o que pode facilitar o processo de acomodação linguística na direção da variante prototípica da comunidade em que ela se inseriu. 


\subsection{O comportamento das fricativas coronais em coda silábica e suas fronteiras dialetais}

Diversos estudos de cunho variacionista já descreveram o comportamento do /S/ em posição de coda silábica medial, dentre os quais Callou, Leite e Moraes (2002, apud PEDROSA, 2009), nas capitais Recife, Salvador, Rio de Janeiro e São Paulo, Brescancini (2002), em Florianópolis, Hora (2003) e Pedrosa (2009), em João Pessoa. Os estudos mencionados apontam quatro possibilidades de variantes para essa variável: a forma alveolar, como em "ca[s]ca"; a forma palatal, como em "pa[S]ta"; a forma aspirada, como em "me[h]mo"; e o zero fonético, como em "me $[\phi] \mathrm{mo}$ ". As mais recorrentes nos dialetos do PB, entretanto, são as duas primeiras, e, a depender da cidade ou região do Brasil, há o predomínio de uma delas. João Pessoa e Recife, ambas capitais de estados vizinhos (Paraíba e Pernambuco, respectivamente), apresentam realidades bastante distintas com relação à utilização da variável em questão, mesmo estando a apenas $120 \mathrm{~km}$ de distância. As subseções seguintes reportam resultados sobre o comportamento da fricativa coronal em coda medial realizados nessas duas comunidades de fala.

\subsection{O /S/ em coda medial na comunidade de João Pessoa-PB}

Hora (2003), a partir dos dados que compõem o corpus do Projeto Variação Linguística no Estado da Paraíba (VALPB), coletados em 1993, analisou o uso das variantes do /S/ em posição de coda silábica medial dentro de uma abordagem laboviana clássica. O Gráfico 1 apresenta a distribuição geral das variantes na comunidade em questão: 


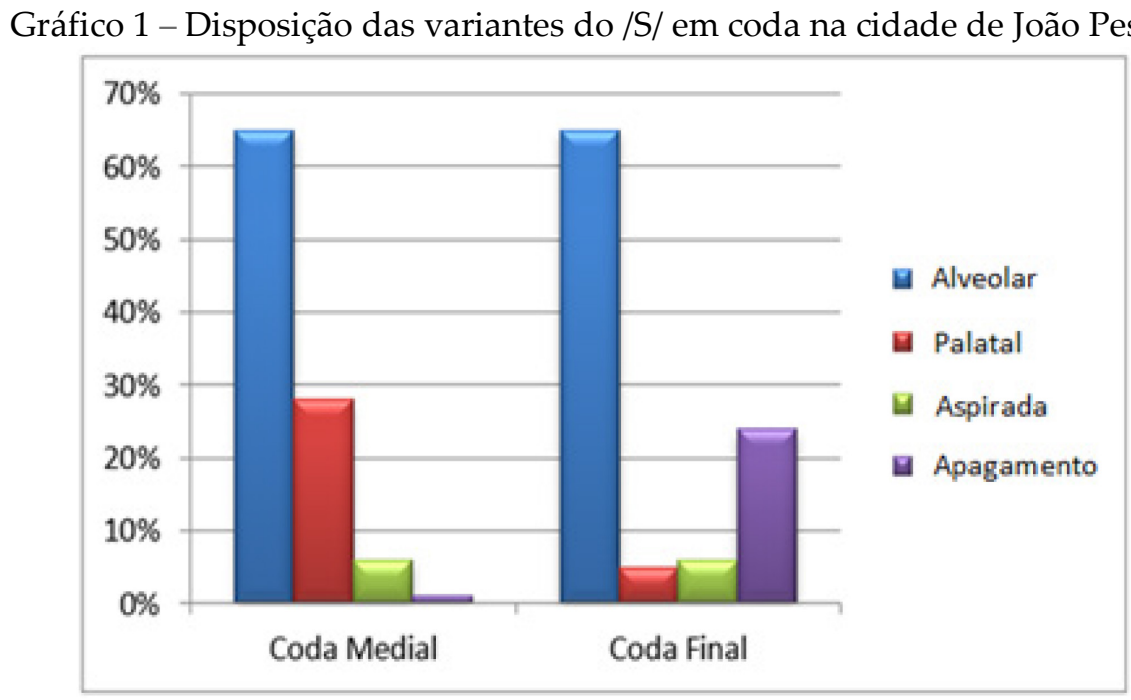

Fonte: Hora (2003) apud Henrique (2016, p. 40)

Hora (2003) constatou a predominância do uso da variante alveolar (65\%) com relação às demais em João Pessoa. A presença da variante palatal em $28 \%$ das ocorrências foi justificada pelo autor pela presença de uma regra de palatalização que é condicionada pelas consoantes oclusivas $/ t$, $d /$ como contexto fonológico seguinte às fricativas. Dessa forma, palavras como "castelo", "estrela" e "desde" são produzidas, prototipicamente, como "ca[J]telo", e[J]trela" e "de[3]de", pelos falantes dessa comunidade de fala. Tal fato foi constatado pelo autor a partir da observação dos resultados da rodada no Goldvarb, que apontou a variável "contexto fonológico seguinte" como a única condicionante para a aplicação da regra de palatalização, conferindo à variante "coronal" um peso relativo de 0.86 .

Trabalhos envolvendo percepção e atitude também atestaram que o ouvinte pessoense não só percebe a distinção entre alveolares e palatais na posição de coda medial, como também imprime juízos de valor a essa variante. O trabalho de Hora (2011) reporta resultados de uma análise qualitativa sobre as respostas de falantes pessoenses em um inquérito sobre o seu dialeto e outros dialetos do Brasil, instrumento baseado na "abordagem direta" para observação de atitudes linguísticas. No que se refere ao uso da forma palato-alveolar, os entrevistados o apontaram como "chiado" e "falar assoprando", e o associaram ao falar carioca. 
Hora (2011) afirma que esse dado evidencia a percepção da variante pela comunidade e sua configuração como estereótipo, segundo a classificação laboviana.

Outro trabalho que apresenta dados pertinentes dentro desse escopo foi o desenvolvido por Lima (2013), analisando o processo de acomodação linguística por pessoenses residentes em Recife. Ela buscou identificar se paraibanos que moraram há, no mínimo, dois anos em Recife, convergiram sua fala em direção ao dialeto recifense, ou seja, ampliaram o uso das variantes palatais em posição de coda medial em outros contextos, além do precedente a /t/ e /d/. Seu arcabouço teórico foi a Teoria da Acomodação da Fala (GILES, 1973 apud GILES, 1991), que postula que o indivíduo, com o objetivo de garantir a aceitação social, tenta convergir a sua maneira de falar de acordo com a do seu interlocutor. Na análise quantitativa, Lima (2013) verificou que o "tempo de permanência" foi a variável mais significativa, dentro da qual a variante "mais de 10 anos" foi apontada como condicionante à aplicação da regra de palatalização do/S/ em contexto diferentes de /t/ e /d. Partindo para uma análise qualitativa, a pesquisadora percebeu que a avaliação positiva em relação ao dialeto recifense contribuiu para os informantes que há mais de 10 anos acomodarem-se ao dialeto recifense, ao passo que a avaliação negativa condicionou a manutenção do dialeto de origem de uma das informantes, que reside em Recife há mais de 10 anos.

Lopes (2012) desenvolve um estudo sobre atitudes de 105 ouvintes pessoenses quanto à ocorrência ou não da palatalização. Aos participantes foram apresentados pares da mesma palavra realizada com as duas pronúncias (por exemplo, história e hi[J]tória), ao que eles deveriam responder se percebiam diferenças entre o sotaque regional e suavizado, além de selecionar qual o tipo de pronúncia que preferiam para a fala de apresentadores de telejornal, para a fala dos pessoenses e para a própria fala. No que diz respeito à palatalização do /S/ em coda 
medial antes de /t/ e /d/, os juízes perceberam que as pronúncias eram diferentes em 95,24\% dos casos. Quanto à forma preferida para a fala de um telejornalista, a variante alveolar foi apontada em $76,48 \%$ das escolhas. Entretanto, quanto à variante preferida para a fala pessoense e para a própria fala, a predominância foi para a variante palatal, que totalizou $68,8 \%$ e $64,20 \%$ das escolhas, respectivamente. Lopes (2012) conclui, a partir desses dados, que ouvintes pessoenses distinguem proficientemente alveolares de palatais em posição de coda silábica nos contextos favorecedores à aplicação da regra de palatalização no dialeto pessoense, e o estilo parece ser um fator importante para o status variante palatalizada nesses contextos a depender da Formalidade (fala do telejornalista) vs. Informalidade (vernáculo pessoense).

A pesquisa de Henrique (2016) buscou analisar, analogamente ao trabalho de Lopes (2012), como os ouvintes percebem as variantes alveolar e palatal do /S/ na posição de coda medial em sua comunidade de fala observando se a distinção alveolar/palatal é percebida de forma diferente, numa escala numérica, em diferentes contextos fonético-fonológicos seguintes; verificando se os ouvintes pessoenses têm consciência do comportamento da variante no seu próprio dialeto, ou seja, se percebem qual variante utilizam com relação aos diversos contextos seguintes; e também se acreditam que sua pronúncia corresponde à pronúncia preferencial de sua comunidade de fala no que diz respeito ao processo analisado. A partir dos resultados de três testes de percepção, Henrique (2016) constatou que os ouvintes atribuem o mesmo grau de diferença ao par de fricativas independentemente do contexto seguinte, que eles têm consciência do comportamento da fricativa do dialeto pessoense, levando em consideração os dados de produção levantados por Hora (2003), e que há uma grande identificação entre esses falantes e o dialeto de sua comunidade de fala em relação à palatalização da fricativa coronal. 
Como a análise descrita neste artigo leva em conta a fala de crianças pessoenses, espera-se que a taxa de ocorrência da variante alveolar seja mais produtiva entre os dados coletados, sendo a variante palatal restrita a contextos fonológicos seguintes preenchidos por consoantes coronais (principalmente $/ \mathrm{t} / \mathrm{e}$ $/ \mathrm{d} /)$.

\section{$2.4 \mathrm{O} / \mathrm{S} / \mathrm{em}$ coda medial na comunidade de Recife-PE}

Tendo por base os dados do Projeto da Norma Urbana Culta (Nurc), Callou, Moraes e Leite (2002, apud PEDROSA, 2009) analisaram o comportamento das consoantes /l/, /S/ e /R/ em coda silábica medial e final na fala de universitários, estratificados em relação à idade (de 25 a 35 anos; de 36 a 55 anos; e de 56 em diante), sexo e origem demográfica, de cinco capitais brasileiras: Rio de Janeiro (RJ), São Paulo (SP), Porto Alegre (RS), Recife (PE) e Salvador (BA). Com relação aos dados de Recife-PE, os autores constataram que, na posição medial, a variante palatal ocorreu em $84 \%$ dos contextos analisados, enquanto a alveolar ocorreu em apenas $10 \%$. A variante aspirada e o apagamento apresentam $5 \%$ e $2 \%$, respectivamente. Na posição final, $54 \%$ das ocorrências foram de produções palatais, enquanto $34 \%$ foram de produções alveolares. A variante aspirada e o apagamento representam $7 \%$ e $5 \%$ desse contexto, respectivamente. O Gráfico 2 resume os resultados desse estudo:

Gráfico 2 - Disposição das variantes do /S/ em coda na cidade de Recife.

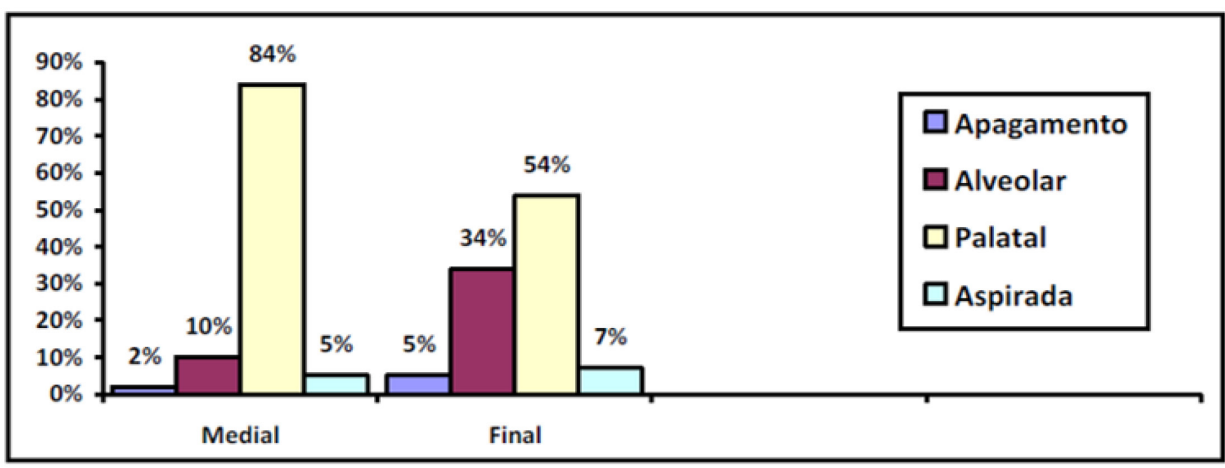

Fonte: Callou, Leite, Moraes (2002) apud Pedrosa (2009, p. 24). 
Macedo (2004) realizou uma análise quantitativa das realizações do /S/ em coda silábica no falar culto recifense, a partir de dados extraído de doze inquéritos do tipo DID (Diálogo entre Informante e Documentador) do corpus do Projeto NurcRecife. Seu objetivo era descrever, a partir de análises estatísticas, que variáveis linguísticas e extralinguísticas condicionaram a regra de palatalização no falar culto de Recife. A Tabela 1 mostra o valor bruto e a proporção de ocorrência de cada uma das variantes analisadas. Percebe-se, de início, a prevalência da variante palatal (76\%) sobre a alveolar (24\%), o que contrasta fortemente com o comportamento dessa variável em João Pessoa, segundo os dados de Hora (2003).

Tabela 1 - Frequência global das variantes do /S/ em coda silábica.

\begin{tabular}{r|r|c} 
Variante & \multicolumn{1}{|c|}{ Aplic./Total } & Frequência \\
\hline Palatal & $2.980 / 3.911$ & $76 \%$ \\
\hline Alveolar & $931 / 3.911$ & $24 \%$
\end{tabular}

Fonte: Macedo (2004, p. 48).

Utilizando o pacote computacional VARB2000, com base em uma análise estatística do tipo step up, Macedo (2004) apontou como significativamente relevantes cinco das oito variáveis consideradas para esta análise. Foram elas, na ordem de relevância apontada pelo programa: sexo, contexto fonológico seguinte, traço [voz] do segmento seguinte, faixa etária e posição da sílaba. Para este artigo, apenas a variável "contexto seguinte" é importante em termos comparativos. A autora averiguou que os usos de palatais são bastante recorrentes em todos os contextos seguintes, mas a maior taxa de aplicação da regra de palatalização acontece quando o /S/ precede uma consoante coronal, sendo essa variante a apontada pelo programa como favorecedora ao uso da forma palatalizada. 
Tabela 2 - Relevância do contexto fonológico seguinte para a palatalização.

\begin{tabular}{r|r|r|r}
\multicolumn{1}{c|}{ Fator } & Aplic./Total & Frequência & Peso Relativo \\
\hline Dorsal & $441 / 564$ & $78 \%$ & .43 \\
\hline Labial & $732 / 1.001$ & $73 \%$ & .44 \\
\hline Coronal & $1.194 / 1.361$ & $88 \%$ & .67 \\
\hline Pausa & $\begin{array}{c}613 / 985 \\
\text { Fonte: Macedo (2004, p. 54). }\end{array}$ & .36
\end{tabular}

Outro dado interessante apontado por Macedo (2004) é o fato de o sexo feminino ser também condicionante para a aplicação da regra de palatalização. Entre as mulheres, o uso da forma palatalizada aconteceu em 92\% das ocorrências de /S/ em coda. Como a análise descrita neste artigo leva em conta a fala de crianças do sexo feminino, espera-se que a taxa de ocorrência da variante palatal na comunidade recifense seja equivalente aos dados reportados por Macedo (2004) dentro desse recorte.

\section{Metodologia}

Esta pesquisa é de natureza quantitativa, na medida em que opera com dados empíricos a partir dos quais se fizeram induções após as aplicações de testes estatísticos, e qualitativa, na medida em que analisa respostas subjetivas dadas pelas informantes deste estudo, com o intuito de esclarecer os resultados apontados pela análise quantitativa.

No que se refere às participantes deste estudo, a primeira delas, MCN, tem 10 anos, nasceu em Recife-PE e mora em João Pessoa há 7 anos. Esta pesquisa teve origem a partir de uma conversa com sua mãe, professora universitária na área de Letras da Universidade Federal da Paraíba (UFPB) e também natural de Recife-PE, quando esta afirmou perceber que, entre os 5 e 6 anos, a filha começou a parar de produzir o /S/ em coda como palatal, fazendo uso da forma alveolar no seu lugar. Dessa forma, buscou-se analisar em que medida a menina, que começou a morar em 
João Pessoa entre 2:8 e 3:0 anos - idade em que as fricativas são adquiridas, segundo Oliveira (2002), Mezzomo (2003) e Berti (2006) -, assimilou o dialeto pessoense no que diz respeito à produção da fricativa coronal em posição de coda medial.

Para estabelecer essa comparação, quatro outras meninas foram submetidas aos mesmos experimentos que a primeira. Duas dessas crianças, as informantes JD e $\mathrm{ML}$, nasceram e residem na região metropolitana de Recife-PE, têm 10 anos e estudam no $6^{\circ}$ ano de uma escola estadual localizada no bairro de Maranguape, em Olinda-PE ${ }^{1}$. Tais crianças foram indicadas de forma aleatória pelo diretor da escola, que apenas foi orientado a sugerir a participação de duas meninas de 10 anos que tivessem nascido na cidade e cujos pais também fossem naturais de lá. As outras duas crianças, MAN e SJS, nasceram e residem em João Pessoa-PB, têm 10 anos e estudam em uma escola pública no Bairro dos Estados, na mesma cidade. A escolha das crianças paraibanas foi feita de forma análoga à escolha das crianças pernambucanas.

Os instrumentos de coleta de dados consistiram em um inquérito fonético, uma leitura monitorada (Anexo A) e uma entrevista semiestruturada (Anexo B). O inquérito consistia em apresentar figuras cujos nomes continham a variável analisada em vários contextos linguísticos controlados. A cada figura, a criança deveria falar duas vezes o que observava. Já a leitura monitorada se deu por meio de um texto narrativo de três parágrafos (cuja tipologia é mais familiar aos discentes dessa faixa etária) nos quais as palavras do inquérito fonético estavam diluídas. Por fim, a entrevista semiestruturada foi desenvolvida para captar dados que comporiam a análise qualitativa dos dados, e visou apreender informações sobre como se dava a interação das informantes com sua família, com o ambiente escolar

\footnotetext{
${ }^{1}$ Olinda faz parte da Região Metropolitana de Recife-PE e, devido a isso, acredita-se que é viável a comparação entre as fricativas realizadas pelas participantes olindenses e pela participante recifense residente em João Pessoa-PB.
} 
e com a vizinhança, bem como compreender suas impressões sobre sua forma de falar e de sua comunidade.

As palavras utilizadas no inquérito fonético foram escolhidas para contemplar, principalmente, a variável independente "contexto fonológico seguinte", crucial para a análise aqui proposta. O quadro 1 abaixo as resume:

Quadro 1 - Lista de palavras-alvo controladas no inquérito fonético².

\begin{tabular}{|c|c|c|c|}
\hline Palavra estímulo & Contexto fon. seg. & Vogal precedente & Tonicidade \\
\hline Isqueiro & $\mathrm{k}$ & $\mathrm{i}$ & pretônica \\
\hline Fusca & $\mathrm{k}$ & $\mathrm{u}$ & tônica \\
\hline Pesca & $\mathrm{k}$ & $\varepsilon$ & tônica \\
\hline Espelho & $\mathrm{p}$ & $\mathrm{i}$ & pretônica \\
\hline Cuspe & $\mathrm{p}$ & $\mathrm{u}$ & tônica \\
\hline Espada & $\mathrm{p}$ & $\mathrm{i}$ & pretônica \\
\hline Estrela & $\mathrm{t}$ & $\mathrm{i}$ & pretônica \\
\hline Poste & $\mathrm{t}$ & $\mathrm{o}$ & tônica \\
\hline Festa & $\mathrm{t}$ & $\mathrm{e}$ & tônica \\
\hline
\end{tabular}

Fonte: elaborado pelos autores.

A coleta de dados foi realizada com o gravador portátil Tascam DR-02, cuja precisão de gravação é de $24 \mathrm{bit} / 96 \mathrm{kHz}$. No momento da coleta, a taxa de amostragem do gravador foi ajustada para $44.100 \mathrm{kHz}$ e o microfone (embutido no aparelho) foi posicionado a cerca de $8 \mathrm{~cm}$ da boca das participantes da pesquisa. Com exceção da menina recifense residente em João Pessoa, que teve sua gravação realizada em laboratório com isolamento acústico, todas as coletas foram realizadas na escola em que as informantes estudavam devido à impossibilidade de as levarmos para o ambiente ideal. A sequência da aplicação dos instrumentos de coleta ocorreu da seguinte forma: 1) leitura monitorada, 2) inquérito fonético e 3) entrevista semiestruturada ${ }^{3}$. Tal ordem foi necessária para que as crianças, no

\footnotetext{
${ }^{2}$ A lista com todas as palavras analisadas, além das do inquérito fonético, pode ser vista nos anexos deste artigo.

${ }^{3}$ Adaptada do roteiro de entrevista de Mendes e Oushiro (2013).
} 
momento do inquérito, retomassem a palavra "asno", presente na leitura, visto que tal palavra não é tão recorrente no arcabouço lexical delas.

Como variável dependente, consideramos a pronúncia da variável /S/, que poderia apresentar como variantes a forma "alveolar", "palatal” ou "ambígua”. Para determinar qual variante foi pronunciada, foram considerados os resultados do trabalho de Henrique et al. (2015), que apontam que as fricativas com primeiro pico nas regiões de frequência de 4,0 kHz para baixo são prototipicamente associadas à palatal, e as com pico igual ou acima de $6,5 \mathrm{kHz}$, à alveolar. Dessa forma, o pico espectral de cada fricativa produzida pelas informantes foi observado: quando ocorria numa zona inferior à 4,0 kHz, a produção era considerada "palatal" (Figura 1); quando ocorria numa zona igual ou superior a 6,5 kHz, "alveolar"(Figura 2); quando o pico espectral ficava entre $4,0 \mathrm{kHz}$ e $6,5 \mathrm{kHz}$, a produção era considerada "ambígua" (Figura 3). Essas medidas foram averiguadas através de inspeção visual do espectro de frequência de cada fricativa, obtido através da transformada rápida de Fourier (FFT) calculada pelo software Praat (BOERSMA; WEENINK, 2009).

Figura 1 - Espectro de energia da fricativa produzida pela informante recifense JD, na palavra "festa", com pico espectral na faixa de frequência de 3,33 kHz.

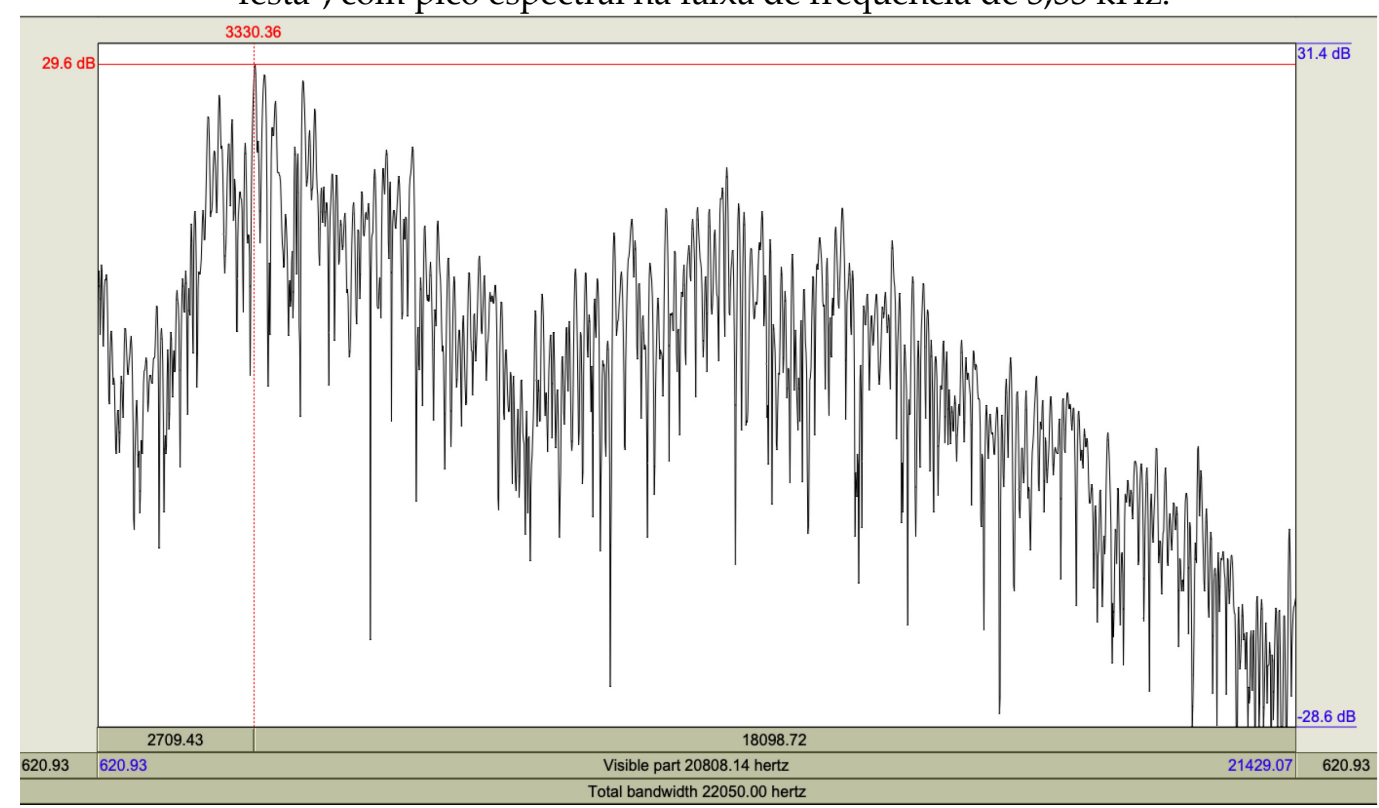

Fonte: pesquisa direta, 2019. 
Figura 2 - Espectro de energia da fricativa produzida pela informante pessoense SJS, na palavra "espelho", com pico espectral na faixa de frequência de 9,55 kHz.

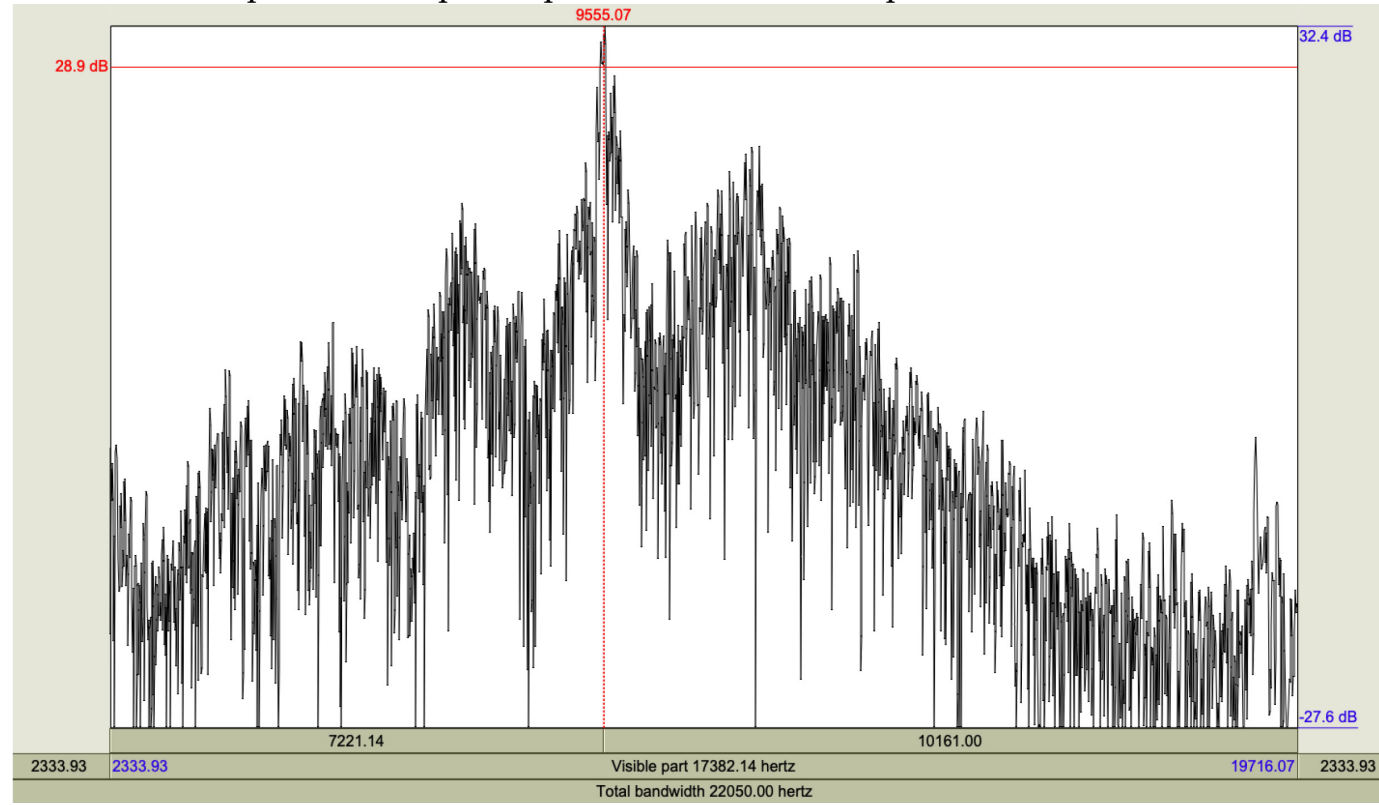

Fonte: pesquisa direta, 2019.

Figura 3 - Espectro de energia da fricativa produzida pela informante migrante $\mathrm{MCN}$, na palavra "espelho", com pico espectral na faixa de frequência de $5,43 \mathrm{kHz}$.

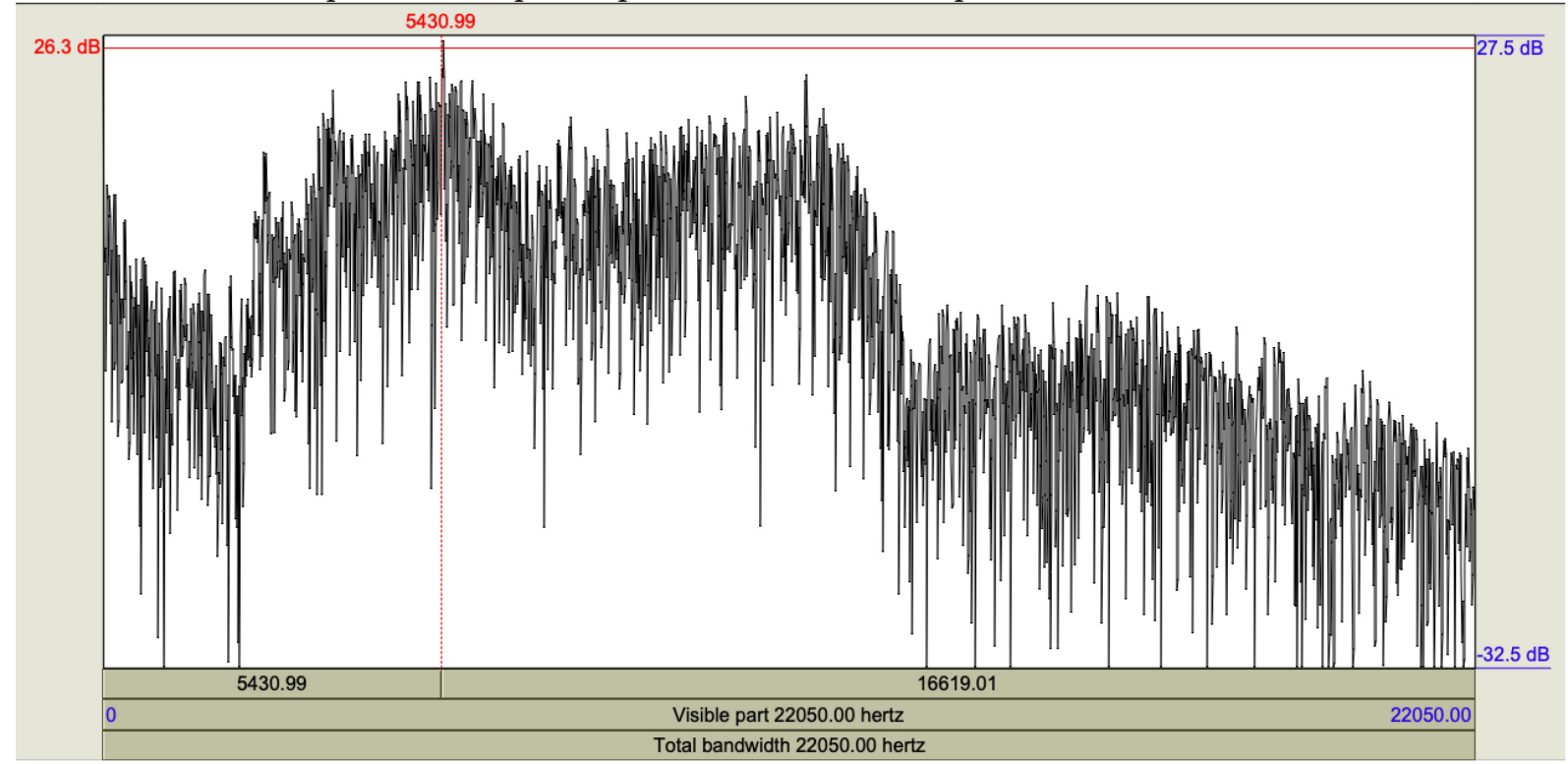

Fonte: pesquisa direta, 2019.

Para as análises quantitativas, utilizamos o programa R (R Core Team, 2019). Já para as análises qualitativas, utilizamos as informações fornecidas por quatro participantes no item "Avaliações linguísticas" da entrevista semiestruturada. 


\section{Resultados}

A partir da quantificação dos dados, obtivemos resultados que nos informam da distribuição das variantes do /S/ por comunidade de fala e por contexto fonológico seguinte. Os gráficos abaixo os expõem.

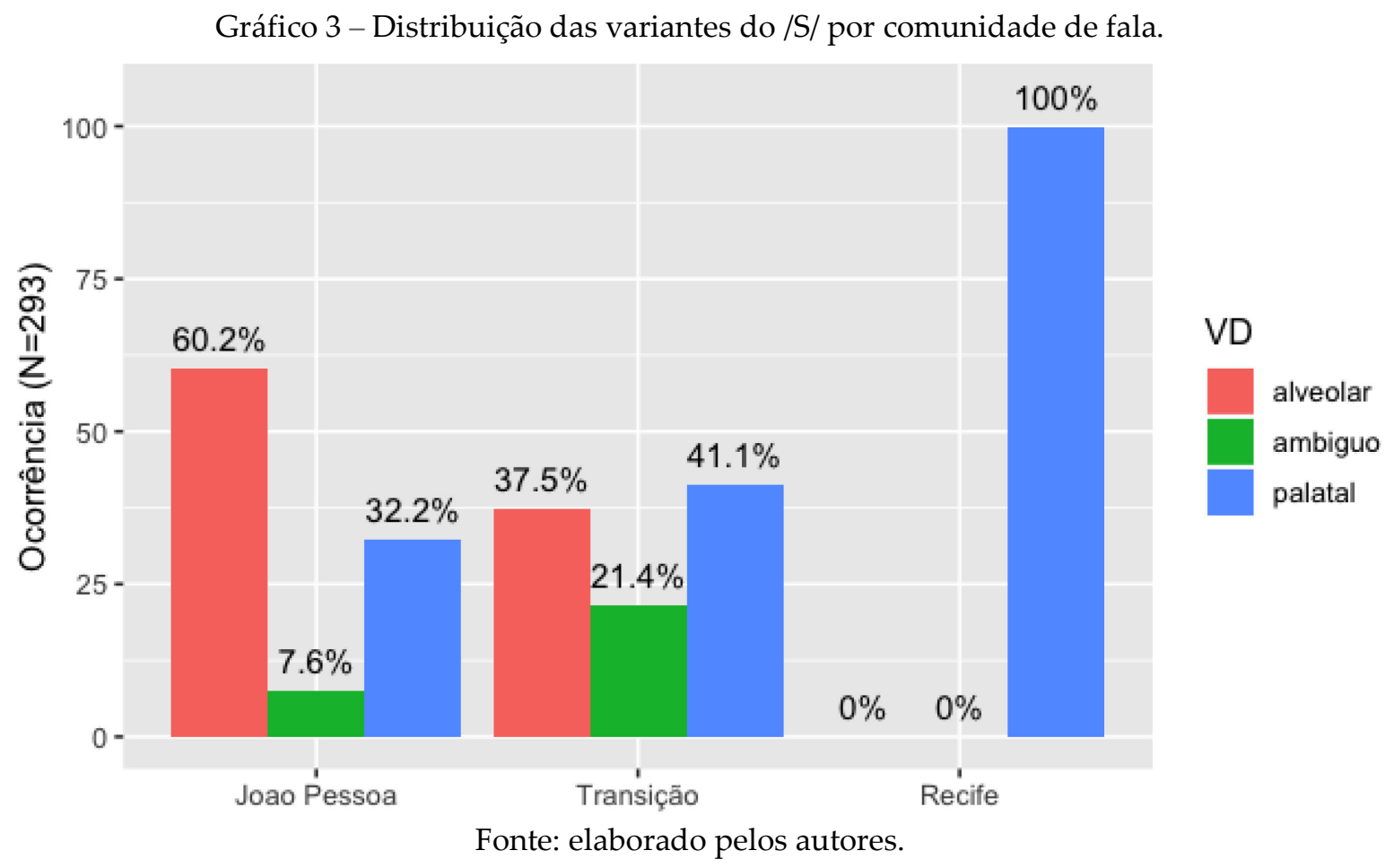

O Gráfico 3 diz respeito ao uso da fricativa coronal em coda medial nas três comunidades de fala pesquisadas, João Pessoa (60,2\% alveolar e 32,2\% palatal), Recife (100\% palatal) e transição (41,1\% palatal e 37,5\% alveolar). Nomeamos como legenda do eixo " $\mathrm{x}$ " as participantes, respectivamente, de João Pessoa, Recife e Transição. Essa última é composta pela participante $\mathrm{MCN}$, a falante migrante e, devido a isso, seu comportamento linguístico aparentemente está passando por um processo de acomodação, ou seja, por uma "transição". Conforme pode-se observar, a variante palatal é a mais produzida pelas recifenses e por $\mathrm{MCN}$, seguida das pessoenses. Os dados corroboram os resultados obtidos por Hora (2003) e Callou, Leite e Moraes (2002, apud PEDROSA, 2009, p. 24), em que a produção da variante 
alveolar em coda medial ocorre em 65\% em João Pessoa e a variante palatal em 80\% em Recife.

Em seguida, o Gráfico 4 apresenta a distribuição das variantes (agrupadas agora em duas categorias, palatal e não palatal) por contexto fonológico seguinte, entre as pessoenses, recifenses e a informante recifense residente em João Pessoa, a qual chamamos de "Transição".

\section{Gráfico 4 - Palatalização por comunidade de fala e classe natural do segmento seguinte.}

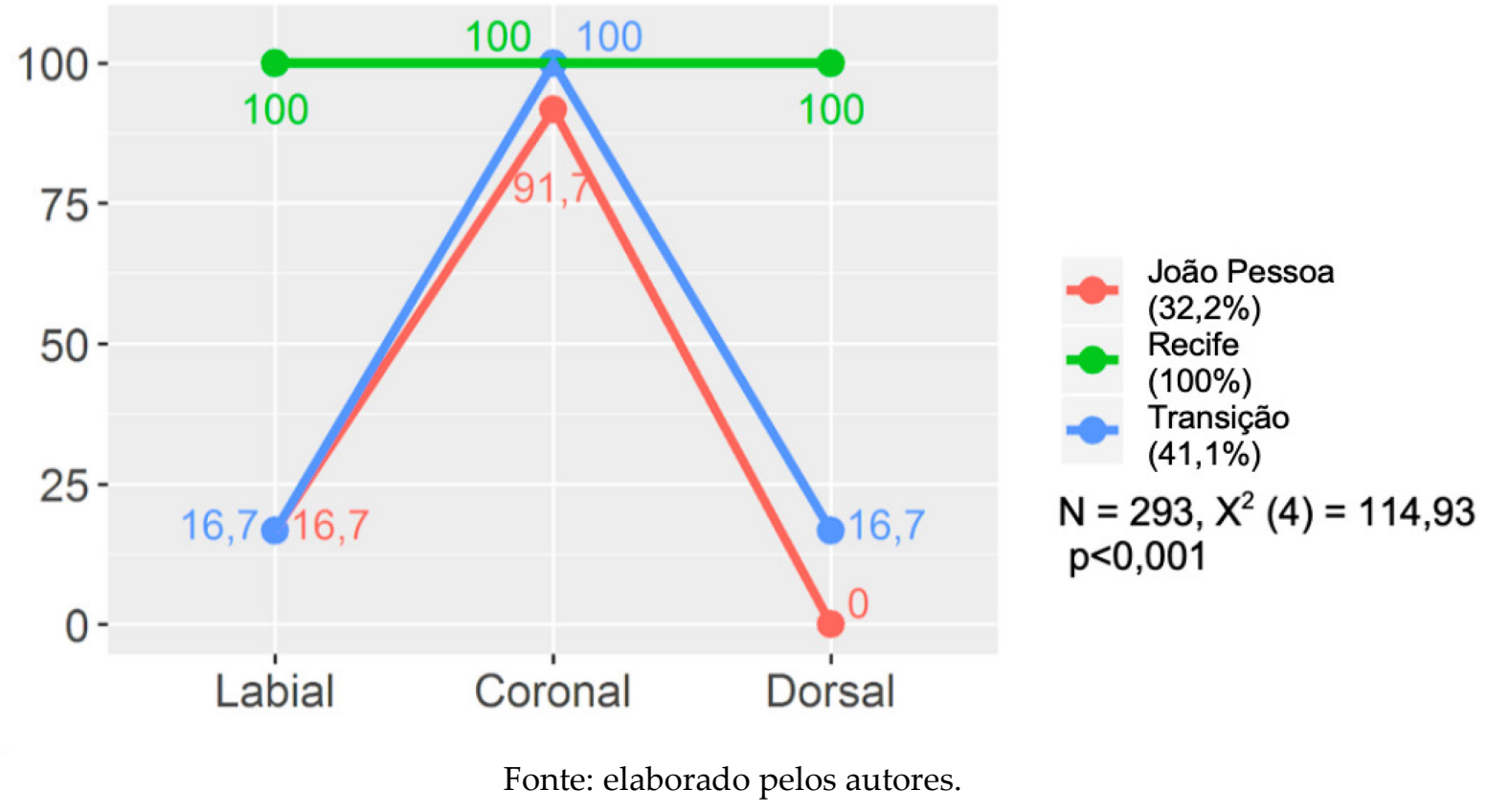

Nota-se que há diferença nas produções do /S/ pelas falantes pessoenses a depender do contexto fonológico seguinte. No caso das recifenses (representadas pela linha verde), as produções do /S/ foram todas palatais, não havendo diferença contextual nessas produções. Evidencia-se então a diferença entre as produções do /S/ pelas falantes pessoenses e as recifenses. A linha azul, que representa a taxa de palatalização da criança migrante, comporta-se de forma análoga à curva rosa, que representa o comportamento da variante palatal entre as falantes de João Pessoa. Um teste de qui-quadrado foi utilizado para averiguar a influência da variável 
comunidade na ocorrência da variante palatal na fala das entrevistadas ${ }^{4}$, que se mostrou significativa $\left(\mathrm{N}=293, \chi^{2}(4)=114,93, \mathrm{p}<0,001\right)$. Os resultados podem dar evidência à hipótese de que a criança recifense, nos contextos fonológicos seguintes, está realizando um processo de acomodação linguística em relação às fricativas, havendo uma substituição da produção da variante palatal pela variante alveolar, cuja ocorrência é mais presente em João Pessoa. Com base nos gráficos apresentados, é notório que o comportamento linguístico de $\mathrm{MCN}$ se assemelha mais com o das pessoenses do que com o das recifenses. Além disso, há outra informação que indica o processo de acomodação linguística da criança: ela parece ter mais realizações "ambíguas" que as demais, evidenciando que o padrão das fricativas não é absolutamente idêntico ao da comunidade de fala pessoense. Fica claro, portanto, que a identidade linguística da menina se dá, atualmente, por meio do uso da fricativa alveolar, o que pode ser justificado como um meio de busca pela aceitação na comunidade de fala em que atualmente reside.

Das cinco crianças participantes da pesquisa, apenas duas, uma olindense (informante $\mathrm{ML}$ ) e a recifense residente em João Pessoa (informante $\mathrm{MCN}$ ), demonstraram consciência da variação da fala. Essa última, por sua vez, demonstrou consciência fonológica em relação ao fenômeno analisado neste trabalho. Abaixo encontra-se o excerto da entrevista com a informante ML:

Excerto 1 - Entrevistadora: É... Como é que tu acha que as pessoas daqui de Olinda falam? O jeito que elas falam.

Informante ML: O sotaque? Né?

E1: Umhum.

ML: Eu acho legal, acho bonita.

E1: E... Tu acha que fala do mesmo jeito que todo mundo aqui de Olinda?

ML: Acho que sim.

E1: E quando outras pessoas vêm de fora pra cá, tu percebe?

\footnotetext{
${ }^{4}$ As variantes "ambígua" e "alveolar" foram amalgamadas em contraste à "palatal", para a realização do teste de qui-quadrado.
} 
ML: Percebo.

E1: Por que tu percebe?

ML: Porque o sotaque é diferente. É... O nordestino, né...

E1: Hum...

ML: Fala mais do interior. E... São Paulo, Rio de Janeiro fala mais... Um é forte e o sotaque é mais aprumado. (grifo nosso)

A informante ML, ao mencionar a palavra "sotaque" e dizer que, devido a isso, percebe que as pessoas são de "fora", demonstra ter consciência de que os grupos podem, em relação à língua falada, destoar entre si. O fato de ela achar que fala como as pessoas de Olinda, além de achar o seu sotaque "legal" e "bonito", pode indicar que, por meio do dialeto, há um sentimento de pertença em relação ao lugar onde ela mora.

Entretanto, quando analisamos a fala de ML pensando em um contexto que ultrapassa a Região Nordeste, vemos que essa identidade não é tão forte assim. Ao dizer que "o nordestino fala mais do interior" e "São Paulo, Rio de Janeiro fala mais [...] forte e [...] mais aprumado", há uma valoração/hierarquização dos sotaques, na qual os da Região Sudeste se sobrepõem aos da Região Nordeste e isso se dá, consoante Bortoni-Ricardo (2004, p. 34), “[...] por fatores políticos e econômicos".

No excerto da entrevista com a informante $\mathrm{MCN}$, disposto abaixo, pode-se perceber que a criança possui uma percepção da variação acerca do fenômeno analisado neste trabalho:

Excerto 2 - Entrevistador 1: Como é que as pessoas falam aqui em João Pessoa? Você acha que fala como as pessoas daqui ou não?

Informante MCN: Sim, eu falo como as pessoas daqui porque eu saí de Recife aos dois anos.

E1: E como você acha... Qual é a principal diferença que vê entre a fala daqui e a fala de Recife?

MCN: É que os pernambucanos chiam e aqui não. (grifo nosso) 
De acordo com o trecho acima, percebe-se que a informante apresenta consciência em relação à variação linguística. A informante tem convicção de que seu modo de falar converge com o de sua atual comunidade de fala, João Pessoa, e justifica isso com o fato de ter saído aos dois anos de Recife, sua comunidade linguística de origem. Além disso, ao afirmar que “os pernambucanos chiam” e os paraibanos não, a menina expõe a sua compreensão acerca do processo de palatalização do /S/ nos falantes recifenses. Tal informação corrobora os dados quantitativos, uma vez que eles mostraram que a criança tem realizado a forma alveolar do segmento fricativo coronal em coda medial. O uso dessa variante pela informante parece evidenciar que esta tem um sentimento de pertença com a comunidade de fala pessoense, mas por se tratar de um estudo que apresenta limitações no que diz respeito aos dados amostrais da entrevista, é necessária a ampliação de investigação do fenômeno analisado.

Já as duas crianças pessoenses, SJS e MAN, expõem, no momento da entrevista, respostas socialmente desejáveis acerca do seu sotaque. Abaixo encontram-se, respectivamente, os excertos:

Excerto 3 - Entrevistador 2: E como é que as pessoas... Aqui, como é que você percebe que as pessoas falam aqui em João Pessoa?

Informante SJS: Português? (risos)

E2: Português? É... você acha que... É... você acha que você fala como as pessoas daqui? Como as outras pessoas daqui?

SJS: Falo! Português, normal!

Excerto 4 - Entrevistador 2: E como é que as pessoas aqui em João Pessoa, elas falam? Pra você, o que que você acha?

Informante MAN: (em silêncio)

E2: Como elas falam aqui em João Pessoa? Como você acha que é a fala das pessoas aqui?

MAN: Num sei.

E2: Não sabe? Nunca reparou?

MAN: Não. 
Como se pode observar, as pessoenses forneceram uma resposta diferente das demais participantes. A primeira, SJS, refere-se apenas à língua, o português, mas não expõe nenhuma característica específica acerca de sua forma de falar. A segunda, por sua vez, após um momento de silêncio, diz que não sabe, que nunca "reparou" como se dá o comportamento linguístico dos falantes de João Pessoa. Uma possível explicação para isso é que, pelo fato de MCN conviver bastante com as duas comunidades de fala (Recife e João Pessoa), as diferenças dialetais lhe são mais salientes. Além disso, reconhece-se que as respostas obtidas com as participantes podem ter sido motivadas por alguns problemas que a abordagem direta apresenta, como a falta de familiaridade entre o pesquisador e os entrevistados, o grande nível de monitoramento, entre outras questões, o que sugere a necessidade de ampliação desta pesquisa.

\section{Considerações finais}

Apesar do tamanho reduzido da amostra observada impossibilitar generalizações, acredita-se que a utilização de diferentes instrumentos de coleta e meios de análise permitiu que este trabalho levasse a conclusões, apesar de preliminares, satisfatórias, servindo como um piloto para futuras pesquisas. A utilização de uma análise quantitativa, juntamente a uma qualitativa, permitiu uma observação e compreensão mais abrangente dos resultados. A análise quantitativa ofereceu o instrumental para descrever, em termos proporcionais, a distribuição da produção palatal e alveolar do /S/ em posição de coda medial, considerando os contextos fonológicos seguintes e a cidade de origem das informantes; a análise qualitativa, por sua vez, permitiu acessar algumas individualidades de cada informante, incluindo fatores como os de atitudes linguísticas e de identidade de cada uma delas, pistas para a compreensão mais aprofundada acerca dos resultados quantitativos. 
Portanto, de acordo com as discussões, evidencia-se não apenas a contribuição da Sociolinguística para o campo da aquisição da linguagem, mas também a necessidade de tentar compreender os processos fonológicos das crianças como algo que também se insere dentro do escopo da acomodação linguística, levando-nos a refletir sobre as implicações que isso tem para a identidade delas como participantes de uma comunidade de fala. Tais informações contribuem com a ampliação dos estudos em Sociolinguística no que se refere à identidade linguística de falantes. Além disso, o trabalho desenvolvido pode ser ampliado a um estudo de produção que analise o mesmo fenômeno de forma longitudinal (a partir de coletas de fala em intervalos de tempo) com a informante de comportamento linguístico em transição, a fim de ratificar ou não questões voltadas à acomodação linguística.

\section{Referências Bibliográficas}

BERTI, L. C. Aquisição incompleta do contraste entre /s/ e / / em crianças falantes do português brasileiro. 221 f. Tese (Doutorado em Linguística). Lafape, IEL, Unicamp, $2006 . \quad$ Disponível em: http://repositorio.unicamp.br/bitstream/REPOSIP/270657/1/Berti LarissaCristina D.pdf. Acesso em 19 abr. 2019.

BOERSMA, P.; WEENINK, D. Praat: doing phonetics by computer (Version 5.1.05) [computer program]. Retrieved May 1, 2009.

BORTONI-RICARDO, S. M. Educação em língua materna: a sociolinguística na sala de aula. São Paulo: Parábola, 2004.

BRESCANCINI, C. Fonologia e Variação: recortes do português brasileiro. Porto Alegre: EDIPUCRS, 2002.

CHACON, K. A. Contato dialetal: análise do falar paulista em João Pessoa. 2012. 115 f. Dissertação (mestrado em Linguística). Universidade Federal da Paraíba, João Pessoa, 2012.

GILES, H.; RYAN, E. B.; SEBASTIAN, R. J. An integrative perspective for the study of attitudes toward language variation. In: GILES, H.; RYAN, E. B. (ed.). Attitudes 
towards language variation: social and applied context. London: Edward Arnold, 1982. p. 1-19.

GILES, H.; COUPLAND, N.; COUPLAND, J. (ed.). Contexts of Accommodation: Developments in applied sociolinguistics. Cambridge: Cambridge University Press, 1991. DOI https://doi.org/10.1017/CBO9780511663673

GUY, G. A identidade lingüística da comunidade de fala: paralelismo interdialetal nos padrões de variação lingüística. Organon, v. 14, n. 28-29, 2000. DOI https://doi.org/10.22456/2238-8915.30194

HENRIQUE, P. F. L.; SILVA, G. B.; LOPES, L. W. Percepção das fricativas estridentes: a pista acústica para a distinção entre alveolares e palatais utilizadas pelos ouvintes pessoenses. Intersecções, Jundiaí, v. 3, p. 116-134, 2015.

HENRIQUE, P. F. L. A percepção das fricativas coronais em coda medial por ouvintes pessoenses. 2016. 98 f. Dissertação (Mestrado em Linguística). Universidade Federal da Paraíba, João Pessoa, 2016.

HORA, D. Variação dialetal e atitude. In: HORA, D.; NEGRÃO, E. V. (org.). Estudos da Linguagem: casamento entre temas e perspectivas. João Pessoa: Ideia/Editora Universitária, p. 15-36, 2011.

HORA, D. Fricativas coronais: análise variacionista. In: RONCARATI, C.; ABRAÇADO, J. (org.). Português brasileiro: contato lingüístico, heterogeneidade e história. Rio de Janeiro: Letras, 2003.

LABOV, W. Padrões Sociolinguísticos. Trad.: Bagno, M.; Scherre, M.; Cardoso, C. São Paulo: Parábola, 2008.

LOPES, L. W. Preferências e atitudes dos ouvintes em relação ao sotaque regional no telejornalismo. $141 \mathrm{f}$. Tese (Doutorado em Linguística). Universidade Federal da Paraíba, João Pessoa, 2012.

MACEDO, S. S. A Palatalização do /s/ em Coda Silábica no Falar Culto Recifense. 159 f. Dissertação (Mestrado em Linguística). Universidade Federal de Pernambuco, Recife, 2004.

MARQUES, S. M. O. As vogais médias pretônicas em situação de contato dialetal. 2006. 159 f. Tese (Doutorado em Letras e Linguística). Universidade Federal do Rio de Janeiro, Rio de Janeiro, 2006. 
MARTINS, M. S. A palatalização de oclusivas dentais em contato dialetal. 2008, 145 f. Dissertação (Mestrado em Letras e Linguística). Universidade Federal do Rio de Janeiro, Rio de Janeiro, 2008.

MENDES, R. B.; OUSHIRO, L. Documentação do Projeto SP2010 - Construção de uma amostra da fala paulistana. 2013. Disponível em: http://projetosp2010.fflch.usp.br/producao-bibliografica. Acesso em: 15 abr. 2019.

MEZZOMO, C. L. Aquisição da coda no Português Brasileiro: uma análise via teoria de princípios e parâmetros. 2003. 232 f. Tese (Doutorado em Letras) Faculdade de Letras PUCRS. Porto Alegre.

OLIVEIRA, C. C. Aquisição das fricativas /f/, /v/, $\int /$ e /z/ no português brasileiro. 134 f. Dissertação (Mestrado em Letras) - Faculdade de Letras, Pontifícia Universidade Católica do Rio Grande do Sul, Porto Alegre, 2002.

POSSATTI, L. Análise do processo de acomodação linguística de falantes cariocas em João Pessoa. 51 f. Monografia (Graduação em Letras). Universidade Federal da Paraíba, João Pessoa, 2015.

PEDROSA, J. L. R. Análise do /s/ pós-vocálico no português brasileiro: coda ou onset com núcleo foneticamente vazio? 2009. 149 f. Tese (Doutorado em Linguística), Universidade Federal da Paraíba, João Pessoa, 2009.

R CORE TEAM. R: A language and environment for statistical computing. $R$ Foundation for Statistical Computing, Vienna, Austria, 2013. Disponível em: http://www.R-project.org/. Acesso em: 19 abr. 2019.

TRUDGILL, P. Dialects in Contact. Oxford: Basil Blackwell, 1986. 


\section{Anexos}

\section{Anexo A - Leitura monitorada ${ }^{5}$}

Era uma vez um rapaz chamado João. Ele morava perto de um clube de pesca e adorava comer cuscuz. À noite, ele brincava de contar cada estrela que tinha no céu e fazia as anotações com um lápis. Mas o problema é que João adorava brincar com fogo e sempre andava com um isqueiro e uma caixa de fósforo.

Certo dia, João foi convidado para ir a uma festa à fantasia. Ele então decidiu ir vestido de príncipe e, como todo bom príncipe, levou sua espada. Porém João também levou seu isqueiro e sua caixa de fósforo e isso deu a maior confusão. Enquanto se olhava no espelho, o fogo do seu isqueiro queimou a cortina do salão, ocasionando um grande incêndio.

Ele ficou tão desesperado que tentou apagar o fogo com água e até com cuspe, mas nada adiantou. Para se salvar, o rapaz saiu correndo, mas escorregou em uma casca e caiu. Por sorte ele conseguiu se levantar e acabou fugindo em um fusca, mas para desviar de um asno que passava pela estrada, João acabou batendo o carro em um poste. Desde esse dia João aprendeu a lição: nunca mais brincar com fogo.

\section{Anexo B - Roteiro de entrevista}

\section{PARTE I}

\section{BAIRRO (aprox. 5 min.)}

Objetivos: descobrir o grau de enraizamento do informante no bairro onde vive/outros bairros; descobrir o grau de mobilidade da pessoa.

1. Você gosta de morar nesse bairro? Por quê?

(a) Se o informante não mora lá há bastante tempo, ou se nem sempre viveu ali: Em que outros lugares você já morou? Como era lá comparado com esse bairro aqui? Onde você preferia morar?

2. Você conhece algum vizinho do bairro? Como é a sua relação com eles?

\footnotetext{
${ }^{5}$ Embora as palavras "vestido", "desesperado" e "escorregou" apresentem contextos fonológicos em que há a presença da fricativa em coda medial, elas não foram consideradas na análise quantitativa por serem diferentes das que constavam no inquérito fonético.
} 


\section{INFÂNCIA (aprox. 5 min.)}

Objetivos: relaxar o informante (em geral, as pessoas gostam de falar sobre sua infância); obter informações sobre mudanças no bairro/cidade de João Pessoa; grau de mobilidade do informante; obter informações sobre escolaridade.

3. Você brinca na rua (no bairro)/dentro de casa/em casa de amigo (onde)? Quais as brincadeiras favoritas?

4. Como são os seus pais? São rígidos?

5. Qual é o seu maior sonho? O que você quer ser quando crescer?

6. Você já passou por alguma situação que você considera ter sido muito perigosa? Conte como foi.

\section{FAMÍLIA (aprox. 5 min.)}

Objetivos: obter informações sobre rede social do informante, grau de enraizamento no bairro/cidade

7. (Se o informante tem irmãos) Como é a sua relação com seus irmãos? (Se o informante não tem irmãos) Você gostaria de ter irmãos? Por quê?

8. Quando seus (pais/avós) vieram pra João Pessoa? Você sabe por que eles vieram?

\section{ESCOLA/OCUPAÇÃO (aprox. 5 min.)}

Objetivos: obter informações sobre rede social do informante; características socioeconômicas

9. Você estuda aqui por perto? (se não souber onde a pessoa estuda)

10. Como eram/são as escolas que você já estudou? Você gosta de ir para a escola?

11. Tem algum professor que você goste muito? Tem algum professor que você não goste?

12. Você gosta de estudar? Por quê?

13. Qual a sua matéria preferida? Por quê?

\section{LAZER (aprox. 5 min.)}

Objetivos: obter informações sobre rede social do informante; mobilidade na cidade; características socioeconômicas

14. E nas horas de lazer, o que você e sua família gostam de fazer? (Se saem, vão pra que lugares?)

15. Com que frequência vai ao cinema? Tem algum filme/série predileto? Qual? Sobre o que se trata?

16. Você passa muito tempo no celular ou tablet? Por quê? Gosta de algum tipo de jogo? Qual? Como ele é?

17. Você costuma viajar? Para que lugares já viajou? Que lugares gostaria de conhecer? Por quê? 


\section{SOAPBOX (aprox. 5 min.)}

18. Você acha que existe coisa/brincadeira de menino e brincadeira de menina? Por quê?

\section{PARTE II}

\section{A CIDADE DE JOÃO PESSOA (aprox. 5 min.)}

19. Você gosta de morar em João Pessoa? (Se não, em que lugar preferiria morar?) Por quê?

20. O que você mais gosta em João Pessoa? Por quê?

21. O que você não gosta em João Pessoa? Por quê?

\section{AVALIAÇÕES LINGUÍSTICAS (aprox. 5 min.)}

22. E como é que as pessoas falam aqui em João Pessoa? (evitar usar a palavra "sotaque"). Você acha que fala como as pessoas daqui? (Se a resposta for não) Quais as diferenças?

\section{Anexo C - Lista de palavras analisadas na entrevista}

$\begin{array}{ll}\text { acostumei } & \text { esquadrão } \\ \text { assisti } & \text { esqueci } \\ \text { assistia } & \text { estagiária } \\ \text { assistindo } & \text { estranhos } \\ \text { assisto } & \text { estudando } \\ \text { bastante } & \text { estudar } \\ \text { cristo } & \text { estudava } \\ \text { Disney } & \text { estudei } \\ \text { escada } & \text { estudo } \\ \text { escalar } & \text { estudos } \\ \text { escola } & \text { expressões } \\ \text { escolher } & \text { festa } \\ \text { esconde } & \text { gosta } \\ \text { escorrego } & \text { gostei } \\ \text { escuto } & \text { gosto } \\ \text { Espanha } & \text { restaurante } \\ \text { espanhol } & \text { suspense }\end{array}$

